\title{
Giraffen Marius som den närvarande referenten - en epilog
}

\author{
SIMON EKSTRÖM \& LARS KAIJSER
}

Det faller på redaktörernas lott att avrunda denna antologi. Och vi gör det genom att ta avstamp i ett samtal från en större tillställning som en av oss nyligen besökte. En av gästerna berättade att han under en resa till Island blivit bjuden på en carpaccio (mycket tunt skurna skivor) gjord på delfin och fortsatte med att redogöra för vilka motstridiga känslor som anrättningen väckt inom honom. Visserligen tog han för sig från fatet och kunde konstatera att det var mycket gott. Men att det var just delfinkött som serverades var definitivt något som inverkade på den kulinariska upplevelsen. Samtidigt noterade han att om det som serverades istället varit tunnskurna skivor av tonfisk hade samma obehagskänsla inte infunnit sig. Men med delfinen var det alltså annorlunda. Av någon anledning aktualiserades alltså en etisk problematik som han menade att tonfisken inte skulle ha väckt. ${ }^{.}$Delfinen framstod helt enkelt som mycket mindre mat än tonfisken. Men om den nu inte på ett självfallet sätt kvalificerade sig som mat, vad var den då?

Den ätandes skepsis tangerar en av de frågor som Michell Zethson (tidigare Göransson) skriver om i sitt bidrag till antologin, nämligen att det är långtifrån givet vilket kött som kan passera som ätbart. Somliga djur uppfattas som mer mat än andra och kött från vissa djur tenderar att inte alls omfattas av konceptet mat. Givetvis är detta också en fråga om kultur och tradition. På många håll i världen äter man såväl delfiner, 
hundar som marsvin, det vill säga djurslag som i flertalet västliga länder inte räknas som tillhöriga de ätbara andra (se Göransson 20I7). Vilket inte innebär att kulturella preferenser inte kan ändras över tid, eller av nödvändighet. Idag diskuteras i länder som Sverige insekter och larver som ett framkomligt sätt att åstadkomma en mer klimatanpassad och hållbar produktion av animaliskt protein än den som tillhandhålls från andra mer etablerade "köttdjur", som nöt, lamm och fägel. Framtiden får utvisa hur det går med satsningen på insekter som ersättning för hamburgare och kycklingfilé. För vår del är det intressantare att borra vidare i frågan om varför gästen på den isländska bjudningen kände ett stråk av motvilja vid tanken på att sätta tänderna i ett stycke delfinkött. Förklaringen torde vara att trots att djuret här uppträder i dött och finfördelat tillstånd skapar det en direkt länk till den levande delfin som vi är vana vid att föreställa oss som ett intelligent och nästan "mänskligt" maritimt däggdjur. Tonfisken, däremot, är betydligt lättare att tänka sig som endast kött. Intellektuellt vet vi att också det varit en levande varelse, men djuret på tallriken stannar bortom vår medvetna horisont.

Andra djur tränger sig i likhet med delfinen innanför vårt kulturella och känslomässiga pansar (jfr Joy 20I4). Vi ska helt kort återvända till antologins inledning och de protester som vintern 2014 riktades mot Köpenhamns zoo. För rätteligen skulle man ju också kunna vända på det perspektiv som där presenterades och konstatera att det inte alls är underligt att parkens personal äter upp eller skapar en pedagogisk situation kring de egna djuren när dessa har dött eller avlivats. Det är ju knappast så att alla djurskötare eller anställda vid djurparker är vegetarianer. Man skulle till och med kunna gå så långt som att hävda att det vore moraliskt mer tveksamt om man från djurparkernas sida avstod från att ta tillvara de djur som avlivas inom verksamheten. För vad är egentligen alternativet, att de blir sopor?

Faktum är att det tydligen är vad som ofta sker. Margo DeMello (20I2:Iı) berättar om en liknande händelse som den vid Köpenhamns zoo, vilken också briserade i en skandal när en vanligen dold verksamhet plötsligt blev offentlig. Märkligt nog inbegriper även denna historia en namngiven giraff. Enligt DeMello brukade djurparken Rio Grande Zoo, i delstaten New Mexico, destruera döda djurkroppar genom att förpassa 
dem till den lokala soptippen. Men vid något tillfälle missade en anställd att de aktuella kropparna inte skulle slängas i samma behållare som annat avfall vid djurparken, vilket fick till följd att den nyligen avlivade giraffen Kashka hittades bland en mängd osorterat avskräde.

Att giraffer avlivas och obduceras/dissekeras publikt, eller att deras döda kroppar hanteras som sopor, är uppenbarligen något som väcker starka reaktioner. Men vad beror det på? Ett möjligt svar kan knyta an till naturfilmernas förkärlek för att visa upp så kallad karismatisk megafauna (DeMello 20I2:50ff, jfr Ganetz 20I2:60). I detta uttryck innefattas ett brett spektrum av arter, som till exempel de stora kattdjuren, isbjörnar, gorillor, schimpanser, valar, hajar och savannens gräsätande jättar (som giraff, elefant och noshörning). Det handlar alltså om vilda djur som via filmer och andra medier ges utrymme för att de antingen är lika oss själva, framstår som stora och majestätiska, och/eller omfattas av ett rykte som spännande och farliga. Men till den grupp av djur som ofta placeras i blickfånget hör även de som har förmågan att kittla vår fantasi eller väcka starka känslor, som pandor och koalor. Till denna senare kategori skulle man även kunna räkna unga individer av samtliga ovan nämnda arter.

Men när det gäller de döda djurparksdjur som här diskuterats skulle ett alternativt svar också kunna ta fasta på att girafferna Marius och Kashka, liksom djurungarna Molly, Enzo, Knut och Nelson samtliga befinner sig någonstans mellan djurparken och våra egna fullständigt domesticerade sällskapsdjur (jfr Flinterud 20I2). Bland mycket annat kan djurparken även uppfattas som ett materialiserat kontrakt där människor åtagit sig att visa upp enskilda djur mot att dessa blir omhändertagna och får sina behov tillgodosedda. I den meningen är djurparkens djur en del av vår större och utvidgade mänskliga familj. Och man äter inte upp sina familjemedlemmar, att göra så skulle symboliskt likna kannibalism. Gulliga djurungar och arter som av något skäl uppfattas som särskilt karismatiska har allra lättast att blir inkluderade i familjemetaforen. Därför blir protesterna också som mest intensiva när det är något av dessa djur som hamnat på tallriken eller på annat sätt verkar ha behandlats respektlöst efter döden.

Svenska mediers sätt att uppmärksamma och beskriva dödandet och den efterföljande dissektionen av giraffen Marius utgick från ett narra- 
tiv som hölls samman av att man avslöjat något häpnadsväckande och förfärligt. Beroende på perspektiv kan det faktum att Köpenhamns zoo valde att skära upp giraffen inför de besökare som ville titta på också omtalas antingen som ett spektakel eller en pedagogisk handling. Men precis som när Carol Adams (2000 [1990]) skriver om biffens, kotlettens eller fiskpinnarnas osynliggjorda djur går det även att likna djurparkernas sätt att hantera de oönskade djurens övertalighet (eller deras döda kroppar) vid en offentlig hemlighet. Att djurparker ofta tvingas avliva djur på grund av brist på utrymme eller andra hänsyn är något som vi alla rimligen känner till, men inte gärna talar om. Eftersom förfarandet vidrör en vetskap som vi uppfattar som ovälkommen - en kulturell smärtpunkt - föredrar vi att inte tänka vidare på saken.

För betraktar man den mediala rapportering som uppstod kring giraffen Marius mot bakgrund av vad Adams skriver om de tysta fläckar som omger djurets förvandling till kött blir det slutligen också tydligt att den verkliga provokationen inte alls bestod i att Marius blev avlivad eller dissekerad. Det anmärkningsvärda - och det som gjorde att redan upplysningarna om vad som inom kort skulle ske på djurparken kvalificerade sig som en nyhetshändelse - var istället att avlivandet utformades som en publik tilldragelse. Istället för att agera i tysthet gjorde den danska ledningen precis tvärtom. Först informerade man med hjälp av ett pressmeddelande om att en välkänd och knappt könsmogen giraff skulle berövas livet, sedan berättade man helt öppet om vad detta innebar (och inbegrep i den förklaringen både bultpistol och hungriga lejon), varefter man till sist valde att iscensätta ett offentligt skådespel kring öppnandet av den döda djurkroppen.

Medvetet eller omedvetet undergrävde djurparken därmed med sina handlingar den "hemlighet" som dödandet av de egna djurparksdjuren tidigare dolt sig bakom. Genom att ge största möjliga offentlighet åt några av de existerande praktiker som förekommer kring levande och döda djurparksdjur omskapades Marius som en i allra högsta grad närvarande (present) och inte alls fränvarande (absent) referent. Djurparkens agerande gjorde det omöjligt att inte lägga märke till den sortens samband som vårt samhälle $\mathrm{i}$ de flesta andra sammanhang har blivit så bra på att dölja: som att köttet på tallriken faktiskt kommer någonstans ifrån. 
Bultpistolen, de hungriga lejonen och direktörens osminkade förklaring att parken helt enkelt inte kan rymma en växande djurbesättning bidrog till att bryta ett inrotat tabu. Plötsligt stod det klart att drivandet av djurparker även förutsätter dödandet av djur. Och att detta är sant oavsett hur mycket det, med djurparksdirektörens egna ord, än "träffar i hjärtat" (se diskussion s. 13 i Inledningen). ${ }^{2}$

Historien från Köpenhamns zoo förtjänar vår uppmärksamhet därför att den säger något väsentligt om hur de flesta av oss regelmässigt tenderar att skilja mellan djur och djur. För i själva verket var även den famösa dissektionen en pågående praktik på den aktuella djurparken. Avlivade djur brukade öppnas och skäras upp inför publik. Det var alltså inte så att man gjorde något annorlunda än vad man brukade göra. Och ändå gjorde man precis det. För den här gången kom beslutet att gälla en individ som tillhörde den exklusiva gruppen av särskilt karismatisk megafauna. Marius var inte bara ung och namngiven, utan även en giraff. För många människor var det just kombinationen av dessa tre omständigheter som gjorde att dödandet upplevdes som extra svårt att höra talas om. Kanske var det också av betydelse att Marius, som giraff, även tillhör släktet av fredliga växtätare. I alla fall väckte det långt mindre uppståndelse när en annan dansk djurpark, Odense Zoo, våren 2015, i samband med skolornas höstlov, dissekerade ett av sina lejon. ${ }^{3}$

Engagemanget för Marius understryker hur djur kan vara förknippade med starka emotionella upplevelser. De har fått status som mentala figurationer för något som vissa människor tycker är skrämmande, fascinerande eller angeläget. Det allra tydligaste exemplet på en sådan karismatisk megafauna är troligen de stora valarna, som alltsedan början av 1970-talet har kommit att uppfattas som bärare av en andlig dimension som antas ha något viktigt att säga till oss människor (Zelko 20I2). Dessa världshavens jättar svävar som i en blå rymd av kosmisk visdom, ekologisk balans och mänskliga tillkortakommanden. Ofta framställs de som levande urtidsdjur med en intelligens som övertrumfar vår egen. Med sin sång och sina långsamma andetag blir de till magnifika, men lätt sorgliga, påminnelser om den pågående misshushållningen med planetens resurser. Valarna utmålas kort sagt som våra mentala vägvisare, de kan hjälpa oss att hitta fram till oss själva. 


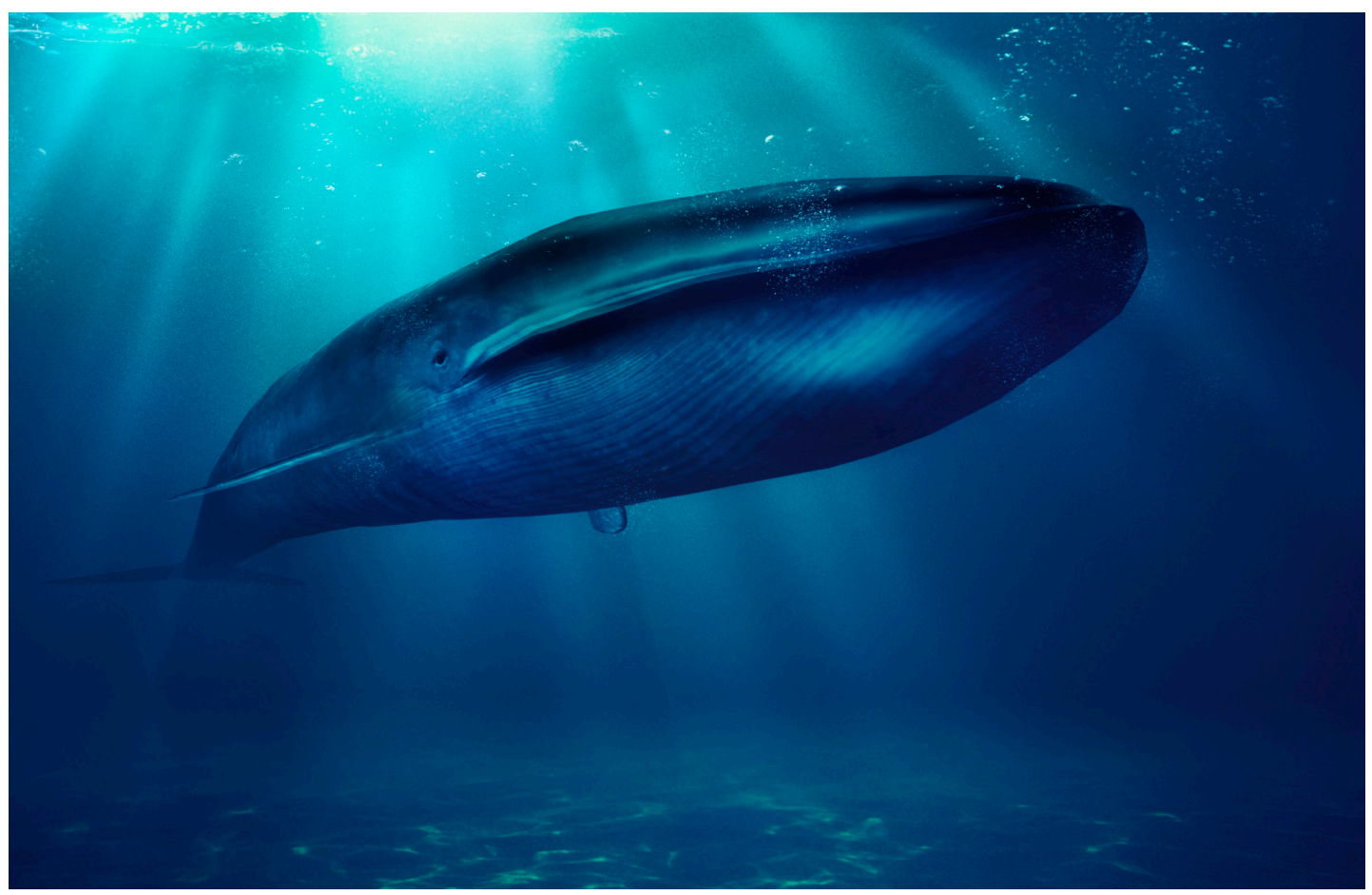

Beskrivningen ovan, av den "andliga valen", är naturligtvis en karikatyr. Men framställningen fångar ändå något av det specifika meningsskapande som i flera sammanhang omgett valen under andra halvan av I900-talet (jfr Mathisen 1996). Valen kan illustrera två av de strukturerande teman som legat bakom bokens upplägg: att vi inte bara känner med, utan också tänker med djur. Valens förebildliga andlighet är dock i själva verket av relativt sent datum. Går vi till andra och tidigare århundraden visar det sig att i den kristna världen förknippades valen under lång tid tvärtom med det bibliska odjuret Leviathan. Konnotationerna till fara och hotande sjömonster, som gigantiska valar, var vanliga på maritima världskartor fram till och med i6oo-talet. Helt och hållet försvann de inte förrän den tekniska utvecklingen under I70o-talet gjorde de långväga sjöresorna både säkrare och mer förutsägbara (jfr Van Duzer 20I3:II8f). Det resulterade, å andra sidan, i att dessa havens jättar under en lång period uteslutande kom att uppfattas i strikt ekonomiska ter-
Valar har länge varit föremål för mänskliga projektioner. Inte minst har de från och med andra halvan av nittonhundratalet knutits till andlighet och kosmisk visdom. För många människor fortsätter valarna att utgöra starka symboler för vår egen arts hänsynslösa utnyttjande av naturen och förlorade kontakt med de egna existentiella rötterna. 
mer, vilket blev upptakten till en kommersiell jakt som under I80o- och det tidiga 1900-talet i flera fall gränsade till total utrotning. Vissa valar, som exempelvis blåvalen och den fortfarande hotade nordkaparen, var med andra ord nära att drabbas av samma sorts utdöenden som Sverker Hyltén-Cavallius diskuterar i sitt bidrag till antologin. Herman Melvilles (1994 [1851]) flera gånger filmade berättelse om hur den oförsonliga valfångaren kapten Ahab genomsöker världshaven för att finna Moby Dick, den vita kaskelott som en gång tog hans ben, kan ses som en brygga mellan dessa två teman: valen som skräckinjagande monster och naturen som slår tillbaka mot människans fruktlösa försök att få den att böja sig efter hennes vilja.

Under senare år har också valar och delfiners närvaro på de större akvarierna och marina temaparkerna varit en stridsfråga. Här har troligen filmen Blackfish (2013), som behandlade späckhuggarnas situation på SeaWorlds anläggning i Florida, fungerat som en viktig ögonöppnare för allmänheten. Uppvisningar med späckhuggare som utför konster har varit ett återkommande inslag på flera av SeaWorlds temaparker, men efter debatterna kring djurhållningen har de signalerat en avsikt att fasa ut uppvisningarna. Om det å ena sidan finns en tydlig artbarriär mellan människor och djur återfinns här ännu ett kulturellt relevant gränssnitt, nämligen det mellan däggdjur och andra djur. Delfiner, späckhuggare och andra valar tillskrivs här ett annat värde än till exempel arter som hajar och havssköldpaddor.

Ytterligare ett välkänt och valrelaterat narrativ, som knyter an till vårt återgivande av den isländska måltiden, är givetvis det om delfinen som människans på en och samma gång lekfulla och jämbördiga, eller till och med överlägsna, kusin från havet. ${ }^{4}$ Att den aktuella rätten väckte ambivalenta känslor var därför till stor del troligen en följd av den nyss beskrivna identifikationen med delfinen/valen. Delfinköttet framstod som en anomali - som något som kunde placeras i det osäkra utrymmet mellan mat och icke-mat - men för vissa av oss skulle nog anrättningen även hota den i de flesta sammanhang noga övervakade gränsdragningen mellan djur och människa.

Återigen understryker resonemanget på hur många olika nivåer som djur är invävda i mänsklig erfarenhet, historia och gestaltning. Flera av 
antologins artiklar har uppehållit sig kring hur vi människor betraktar och på olika sätt visualiserar djur. Författarna har på olika sätt problematiserat hur djur avbildas och introduceras i utställningar och på museer eller liknande inrättningar, men också i skämtteckningar, filmer och muntliga redogörelser.

Också här vill vi stanna upp ett ögonblick för att samla tankarna. Under de senaste decennierna har ett tidigare distanserat betraktande på flera områden fått ge vika för ett mer interaktivt och upplevelseorienterat sätt att ta del av djur och natur. Att ornitologin, som utgör ett gemensamt ramverk för både Susanne Nylund Skogs och Elin Lundqvists bidrag, gått från att under 180o-talet döda sina objekt med gevär till att nuförtiden nöja sig med foton och observationer, må vara ett övertydligt exempel. Men som vi sett kan det levande djuret också utgöra en del av den attraktiva upplevelsen under ett utvidgat restaurangbesök, som inbegriper både jakt och slakt, likaväl som att det vid många museibesök ingår ett moment av att vi som besökare ska känna och uppleva djuren med våra egna sinnen. Den som hösten 2017 besöker Naturhistoriska riksmuseets utställning om nordiska djur får därför inte bara titta på en monterad älg, utan erbjuds också att själv härma älgens lockljud. Ju bättre lockrop från besökaren desto större bild av en älg framträder på skärmen. Den sinnliga erfarenheten kan med andra ord bli ett medel för att formulera det som utgör kärnan i mycket av den kulturvetenskapliga forskningen om relationen människa-djur. I likhet med hur Mattias Frihammar vid ett tillfälle lät handen falla på de upptravade lammskinnspälsarna i Vildmarksnästet i Mo, eller hur Helena Hörnfeldt kände den egna pulsen öka inför den "slemmiga" ormen bakom terrariets glas, blir dessa berörande möten till något som lockar fram och får oss att erfara även djuret i oss själva.

Men även om artiklarna inte saknar iakttagelser och skildringar av konkreta möten över artbarriärerna är det knappast i dessa analyser som vi hittar artiklarnas huvudsakliga ärende. Det egentliga kunskapsmålet ligger någon annanstans. Det kan därför avslutningsvis finnas skäl att återkomma till den icke-mänskliga karisma som flera av författarna använder som ett analytiskt redskap. Detta begrepp klargör nämligen vad som utgör antologins mest bärande förutsättning och tankespår. 
Karisma är inte, och kan inte vara, något absolut. Tvärtom rör det sig om vad vi som människor, förankrade i vår egen historiska situation, erkänner och upplever som kraftfullt, attraktivt, gulligt eller skrämmande. Icke-mänsklig karisma är inget som vissa djur har, utan något som blir till i mötet mellan människa och djur. Som framhölls i inledningen är våra artiklar exempel på kulturella djurstudier. I detta konstaterande ligger att vi fortfarande befinner oss innanför det antropocentriska perspektivet. Det vi studerar är biologisk och kulturell mångfald från ett mänskligt perspektiv. Därmed kan vi nu också avsluta epilogen där vi började: framför den isländska tallriken med tunt uppskuren delfin. Det stråk av obehag som detta uppskurna stycke kött riskerar att väcka till liv visar på delfinens/djurets förmåga att på en och samma gång agera motpart i ett berörande möte och utgöra en tydligt definierad smärtpunkt för våra egna kulturella orienteringar.

NOTER

I. Sedan kan man naturligtvis invända att tonfisken, en av de mest utsatta fiskarna i världen, inte heller är etiskt oproblematisk. Men det var inte poängen i den diskussion som här refereras.

2. Under senare decennier har de zoologiska trädgårdarna fått hård kritik för sin djurhållning (DeMello 20I2:IO3-IO5). Djurparkerna själva har här svarat genom att bl.a. gå samman i organisationer som World Association of Zoos and Aquariums (WAZA) och på så sätt reglera sin verksamhet. De zoologiska parkerna har också strävat efter att argumentera för sin verksamhet mer som artbevarande, än som en uppvisning av djur.

3. Också denna gång rörde det sig om ett ungdjur, en ettårig hanne, som avlivats på grund av ett överskott på lejon i djurparken. Till skillnad från Marius hade det här lejonet dock inte något personligt namn. Se t.ex. Göteborgs-Posten 20I6-oI-I8, Kvällsposten 20I6-OI-I8.

4. När sf-författaren Douglas Adams (I986) i fjärde delen av den internationella bästsäljaren Liftarens guide till galaxen låter delfinerna förmedla ett sista varnande budskap till mänskligheten (strax innan planeten kommer att upphöra att existera till förmån för en intergalaktisk motorväg) visar han alltså upp en ironisk fingertoppskänsla vad gäller beredvilligheten att tillskriva delfiner avsevärda förståndsgåvor. Givetvis saknar människorna i Adams framställning helt förutsättningar att avkoda det komplexa budskapet. 


\section{LITTERATUR}

Adams, Carol 2000 (1990). The Sexual Politics of Meat. A Feminist-Vegetarian Critical Theory. New York: Continuum.

Adams, Douglas 1982. Liftarens guide till galaxen. Stockholm: Alba.

DeMello, Margo 2012. Animals and Society. An Introduction to Human-Animal Studies. New York: Columbia University Press.

Flinterud, Guro 2012. A PolyPhonic Polar Bear. Animal and Celebrity in Twenty-first Century Popular Culture. Oslo: University of Oslo.

Ganetz, Hillevi 20I2. Naturlikt. Människor, djur och växter i SVT:s naturmagasin. Möklinta: Gidlund.

Göransson, Michell 20I7. Ätbara Andra. Göteborg \& Stockholm: Makadam.

Joy, Melanie 20I4. Varför vi älskar hundar, äter grisar och klär oss $i$ kor. En introduktion till karnismen, trossystemet som gör att vi kan äta vissa djur men inte andra. Stockholm: Karneval.

Lejon dissekerades inför publik på zoo. Göteborgs-Posten 20I6-oI-I8.

Lejon styckat - inför publik. Friskt djur dödades och dissekerades på zoo inför barn. Kvällsposten 2016-oI-I8.

Mathisen, Stein 1996."Real Barbarians Eat Whales". Norwegian Identity and the Whaling Issue. Making Europe in Nordic Contexts. Pertti Anttonen (red.). Turku: NIF.

Melville, Herman 1994 (1951). Moby Dick eller Valen. Lund: Studentlitteratur.

Van Duzer, Chet 2013. Sea Monsters on Medieval and Renaissance Maps. London: British Library.

Zelko, Frank 20I2. From Blubber and Baleen to Budha of the Deep. The Rise of the Metaphysical Whale. Society E' Animals, nr 20. 